\title{
Problems Associated with Liquidity Management of Commercial Banks of Bangladesh
}

\author{
Md. Abdullah Al Hasan ${ }^{1} \quad$ Farhana Nasrin ${ }^{2 *}$ \\ 1.Assistant Professor, Department of Finance, University of Chittagong, Postcode (ZIP) : \\ 4331, Hathazari, Chattogram, Bangladesh \\ 2.Lecturer, Business Administration, BGC Trust University, Chandanaish, Chattogram, Bangladesh
}

\begin{abstract}
Liquidity Management is the key to the success or failure of commercial banks irrespective of nature, sizes, and kinds. Although, liquidity is not directly link the generation of profits, but it enables commercial banks to use the funds for generating profits by maintaining economic size of liquidity. Liquidity management, being an integral part of commercial banks, faces numerous problems of different categories. So, a commercial bank has to identify the problems associated with liquidity planning and controlling in order to ensure more effective liquidity management. In view of this, the current study has been undertaken to identify some important problems associated with liquidity management of samples of fifty executive level managers of some private commercial banks in Bangladesh formed by employing sophisticated Varimax Rotated factor Analysis. The study has found that Regulatory and Policy Related Problems, Debt Instrument Problems and Foreign Exchange Market Related Problems are the main warnings that hinder the liquidity position of commercial banks.
\end{abstract}

Keywords: Liquidity, Government Policy and Regulation, Debt Instrument and Foreign Exchange Market DOI: $10.7176 /$ RJFA/10-4-10

\section{Introduction}

Like any other firm, a bank has to manage carefully its liquidity in order to be able to cover mismatches between future cash outflows and cash inflows. However the degree of uncertainty on these mismatches is clearly much higher in the banking sector.

On the liability side, there is obviously a large uncertainty on the amount of withdrawals of deposits (including wholesale) or the renewal of rolled-over inter-bank loans. This is especially so when the bank is under suspicion of insolvency, when there is a temporary (aggregate) liquidity shortage or when the economy suffers from a macroeconomic shock.

On the assets side also, there is some uncertainty on the volume of new requests for loans (or renewal of old loans) that a bank will receive in the future. Of course the bank could refuse to grant these new loans but this would in general lead to the loss of profit opportunities. This would also be detrimental to the borrowing firm if it is credit rationed, and more general to the economy as a whole: we have to remember that banks are unique providers of liquidity to small and medium size enterprises, which constitute an important fraction of the private sector. This credit rationing would be especially costly if the firm is forced to close down, possibly resulting in additional losses for the bank itself.

Off-balance sheet operations are a third source of liquidity risk for banks. Examples are credit lines and other commitments. More importantly, the formidable positions taken by banks on derivative markets can generate huge liquidity needs during crisis periods.

A final source of liquidity risk is large value inter-bank payments, for which Central Banks favor the use of RTGSs(Real Time Gross Settlement) over DNSs(Deferred Net Settlement), because they are less prone to systemic risk. However RGTSs are highly liquidity intensive and can only function properly if banks hold sufficient amount of collateral to back credit lines, either from the Central Bank or from other participants. The failure of a large participant in a large value payment system (LVPS) could provoke a big disruption to the financial system. Even a liquidity shortage or a "gridlock" due to a temporary stop in the payment activity of a large bank could have dramatic consequences. This creates a "too big to fail" issue since it is likely that the Central Bank would be forced to intervene in such a situation. To avoid or simply to mitigate such problems, ex ante regulation of the liquidity of large participants in RTGSs seems warranted.

\section{Literature review}

Researchers have identified problems associated with the liquidity management on the basis of opinions of experts, practitioners and professionals; and review of existing literatures.

Banks have two fundamental characteristics: they play a crucial role in the financing of small and medium firms that do not have a direct access to financial markets and they principally rely on external sources (deposits) for financing these loans. The fact that banks have to screen and monitor their borrowers creates an opaqueness of banks' assets: as shown by Morgan (2002), these assets are difficult to evaluate by external analysts. This opaqueness generates possibilities of moral hazard, in the form of insufficient effort by banks for screening their 
borrowers, or for monitoring their activities after the loan has been granted. Modern corporate finance theory (see Tirole, 2006) has shown that in such a situation, liquidity needs (due for example to costs overruns in the borrowers' projects or to deposits withdrawals in the banks themselves) are insufficiently covered by financial markets. Following Holmström and Tirole (1998), Rochet (2004) studies possible institutional arrangements that can solve this market failure (see also Rochet 2008). For example private contractual arrangements such as pools of liquidity accompanied with inter-bank credit lines commitments can be used to mitigate this inefficiency. This can be a substitute to emergency liquidity assistance by the Central Bank, at least in the absence of aggregate shocks.

Opaqueness of banks' assets also creates an externality between lenders on the inter-bank markets, payment system participants, or between uninsured depositors. The decision to renew a short term inter-bank loan, a debit cap on a large value payment system (LVPS) or a wholesale deposit depends not only on fundamental uncertainty (the quality of the bank's assets) but also on strategic uncertainty (what other lenders or depositors will do). Freixas et al. (2000) study the consequence of such a strategic uncertainty on the risk of contagion on an inter-bank LVPS. In such a context, liquidity requirements can be a way to limit systemic risk. Allen and Gale (2000) also show how contagion can emerge when inter-bank markets are incomplete. Using the methodology of global games popularized by Morris and Shin (1998), Rochet and Vives (2004) show that a combination of liquidity requirements, solvency requirements and LLR interventions may prevent the occurrence of coordination failures on inter-bank markets. Such coordination failures arise when some (large and uninsured) depositors decide to withdraw, not because they think the bank is likely to be insolvent, but because they anticipate others will withdraw. The rationale behind liquidity requirements is that they reduce the impact of strategic uncertainty on the final situation of the bank, since they allow the bank to withstand larger withdrawals. The same is true for solvency requirements and lender of last resort intervention. The difficulty is to determine the appropriate combination of these three instruments that minimizes the total costs of prevention of such coordination failures.

Finally, some form of government intervention may be needed in case of macroeconomic shocks such as recessions, devaluations, stock market crashes and the like. The same is true for disruptions in the payment system. Anticipating on this kind of intervention, banks may decide opportunistically to take an excessive exposure to such risks, knowing that they are likely to be bailed out in case the risks materialize. Rochet (2004) studies this question and shows that ex ante regulation of banks' liquidity maybe a way to mitigate this behavior.

So far as our knowledge goes; no study has been made on the problems associated with liquidity management practices of commercial banks in Bangladesh. So, the researchers have involved in the study of the problems associated with the management of liquidity of private commercial banks in Bangladesh. The objective of the study is to identify the key problems regarding the Liquidity Management of Private Commercial Banks of Bangladesh.

\section{Methodology of the Study}

3.1 Population and Sample

There are 58 Scheduled Commercial Banks operating in Bangladesh. Out of 58, 29 Commercial Banks are listed on both DSE (Dhaka Stock Exchange) and CSE (Chittagong Stock Exchange). There are 6 Islamic Commercial Banks and 23 Conventional Private Commercial Banks out of 29 listed banks. The researcher has selected fifty executive level managers of 23 listed private conventional commercial banks purposively.

\subsection{The Reliability and Validity of data:}

The validity of primary data has been tested through pilot survey i.e. Survey that is conducted with few executives of the target sample of the survey, in order to test and refine the survey instruments.

The reliability of the data has been tested by employing Cronbach's alpha which is a measure of internal consistency that is, how closely related a set of items are as a group. It is considered to be a measure of scale reliability. The alpha value of the present study is .77. This indicates the acceptable level of consistency of data on five point likert scale.

The Kaiser-Meyer-Olkin is used to measure of Sampling Adequacy that indicates the proportion of variance in variables that might be caused by underlying factors. High values (close to 1.0) generally indicate that a factor analysis may be useful with the data. The KMO value of the present study is .82 .

\subsection{Data collection and Analysis}

Primary data has been used in the study. In order to collect primary data, the researcher has prepared a structured questionnaire and made appointments with general branch managers of sample banks. The data has been analyzed by using different relevant techniques as are mean, standard deviation, coefficient of variation, coefficient of correlation and multivariate technique-Varimax Rotated Factor Analysis. 


\section{Findings and Analysis}

4.1 Identification of Problems Associated with Liquidity Management on Mean Scores basis

The researcher has collected opinions of sample professionals on 5 point Likert Scale in order to identify the problems that are associated with liquidity management of selected sample banking companies in Bangladesh. Varimax Rotated Factor Analytical techniques have been employed for grouping the variables on the basis of their inherent relationship and finally ranking the group on the basis of their magnitudes. The study has identified the variables undertaken for the study as most significant, significant and insignificant on the basis of mean score of opinions taken from 5 point Likert scale as shown in Table 4.1.

Table: 4.1: Problems associated with liquidity management practices of sample commercial banks

\begin{tabular}{|c|l|c|}
\hline \multicolumn{1}{|c|}{ Variables } & \multicolumn{1}{|c|}{ Problems } & Mean score \\
\hline \multicolumn{1}{|c|}{ Most Important } & 4.2200 \\
\hline X1 & Nonperforming loan creates liquidity problem & 4.0600 \\
\hline X2 33 & Interest rate difference creates liquidity problem & 4.4800 \\
\hline X8 & Asset liability mismatch has negative impact on liquidity & 4.3000 \\
\hline X10 & Mandatory reserve requirements & 4.2800 \\
\hline Xmportant & & 3.8000 \\
\hline X5 & $\begin{array}{l}\text { Commercial Bank in Bangladesh were quite unwilling to commit their } \\
\text { resources to long term investment }\end{array}$ & 3.9000 \\
\hline X6 & Ahe liberalization of the foreign exchange market & 3.5200 \\
\hline X7 & Positive operations of Central Bank Moral hazards & 3.8000 \\
\hline X11 & Behavior of board of directors \& managing directors & 3.5000 \\
\hline X12 & Shifting from direct instruments to indirect instruments & 3.9400 \\
\hline X13 & $\begin{array}{l}\text { Disagreement between Bangladesh Bank \& commercial Bank } \\
\text { over the use of ideal fund in real sector }\end{array}$ & 3.8000 \\
\hline
\end{tabular}

Source: Survey Instruments

Note: Data have been compiled by the researcher

It is evident from the table 4.1 that the study has identified Asset liability Mismatch as the most significant problem associated with the liquidity management of sample commercial banks on weighted mean basis. It has also identified four other variables, as significant on the same basis. These are mandatory reserve requirements, interest rate difference, failure of legal reserve requirement and Non- performing loan. The study has identified eight variables as important which are quite unwillingness to commit their resources to long term investment, liberalization of the foreign exchange market, Absence of Vibrant term market, Positive operations of Central Bank Moral hazards, Disagreement between Bangladesh Bank \& commercial Bank over the use of ideal fund in real sector, Shifting from direct instruments to indirect instruments, Govt. debt management instruments and Behavior of board of directors \& managing directors.

\subsection{Analysis of correlation Matrix of Problems Associated with Liquidity Management of Sample Commercial} Banks

The study has measured zero-order correlation coefficients (shown in Table 4.2) by employing SPSS (Version23)

Table: 4.2 Correlations Matrix of the problems of the liquidity management of sample commercial banks

\begin{tabular}{|c|c|c|c|c|c|c|c|c|c|c|c|c|c|}
\hline & X1 & $\mathrm{X} 2$ & $\mathrm{X3}$ & $\mathrm{X4}$ & X5 & X6 & $\mathbf{X} 7$ & X8 & X9 & $\mathbf{X 1 0}$ & X11 & X12 & X13 \\
\hline $\mathrm{X} 1$ & 1.000 & & & & & & & & & & & & \\
\hline $\mathrm{X} 2$ & $.594^{\#}$ & 1.000 & & & & & & & & & & & \\
\hline X3 & $.332^{\#}$ & .140 & 1.000 & & & & & & & & & & \\
\hline $\mathrm{X} 4$ & $480^{\#}$ & $.314^{\#}$ & $.425^{\#}$ & 1.000 & & & & & & & & & \\
\hline $\mathrm{X} 5$ & $.281^{\# \#}$ & -.057 & -.011 & $.424^{\#}$ & 1.000 & & & & & & & & \\
\hline X6 & .046 & -.116 & $.356^{\#}$ & $.353^{\#}$ & $.464^{\#}$ & 1.000 & & & & & & & \\
\hline $\mathrm{X} 7$ & .154 & $.220^{\# \# \#}$ & -.014 & $.201^{\# \# \#}$ & .206 & .158 & 1.000 & & & & & & \\
\hline $\mathrm{X} 8$ & $-.234^{\# \#}$ & -.082 & $-.266^{\# \#}$ & .065 & $.299^{\# \#}$ & $.272^{\# \#}$ & $.297^{\# \#}$ & 1.000 & & & & & \\
\hline $\mathrm{X} 9$ & $.280^{\#}$ & $.386^{\#}$ & .049 & $.470^{\#}$ & $.304^{\# \#}$ & $.231^{\# \#}$ & $.351^{\#}$ & $.500^{\#}$ & 1.000 & & & & \\
\hline $\mathrm{X} 10$ & -.088 & .066 & $-.251^{\# \#}$ & -.035 & .087 & $.229^{\# \# \#}$ & $.428^{\#}$ & $.557^{\#}$ & $.191^{\# \# \# ~}$ & 1.000 & & & \\
\hline $\mathrm{X} 11$ & .177 & $.279^{\# \#}$ & $.345^{\#}$ & $.510^{\#}$ & $.372^{\#}$ & $.490^{\#}$ & .169 & $.350^{\#}$ & $.556^{\#}$ & .154 & 1.000 & & \\
\hline X12 & .020 & .025 & -.102 & .076 & .030 & .286 & $.226^{\# \#}$ & .116 & $.277^{\# \#}$ & $.352^{\#}$ & .115 & 1.000 & \\
\hline $\mathrm{X} 13$ & $.443^{\#}$ & $.374^{\#}$ & .048 & $.348^{\#}$ & $.334^{\#}$ & $-.189^{\# \# \# ~}$ & -.038 & -.057 & $.339^{\#}$ & -.057 & .088 & $.196^{\# \# \#}$ & 1.000 \\
\hline
\end{tabular}

Note: Data have been compiled by the researcher

Level of Significance:

\# $1 \%$ level of significance

\#\# 5\% level of significance

\#\#\# 10\% level of significance 
From the perusal of the zero-order correlation matrix of 13 variables, it has been found that some variables have emerged as most significant factors which ultimately form different orthogonal factors. In this case, Variable X1(Non performing loan) has been found highly correlated with variables X2 (Interest rate difference), X3(Asset liability mismatch), X4 (Commercial Bank in Bangladesh were quite unwilling to commit their resources to long term investment) \& X13 (Disagreement between Bangladesh Bank \& commercial Bank over the use of ideal fund in real sector) at $1 \%$ level of significance. This implies that these variables are expected to form a strong group. The study has found that variable X2(Interest rate difference) is highly correlated with variables X4 (Commercial Bank in Bangladesh were quite unwilling to commit their resources to long term investment), X9(Behavior of board of directors \& managing directors), and X13(Disagreement between Bangladesh Bank \& commercial Bank over the use of ideal fund in real sector) at $1 \%$ level of significance.

It has been observed that variable $\mathrm{X} 3$ (Asset liability mismatch) is highly correlated with variables $\mathrm{X}_{4}$ (Commercial Bank in Bangladesh were quite unwilling to commit their resources to long term investment), $\mathrm{X}_{6}$ (Absence of Vibrant term market) and X11(Shifting from direct instruments to indirect instruments) at $1 \%$ level of significance. It has also been observed that Variable X4 (Commercial Bank in Bangladesh were quite unwilling to commit their resources to long term investment) is highly correlated with variables X5 (The liberalization of the foreign exchange market), X6 (Absence of Vibrant term market), X9 (Behavior of board of directors \& managing directors) and X11(Shifting from direct instruments to indirect instruments) at $1 \%$ level of significance. This signifies that liquidity management is significantly associated with market environment and forces. The study has found that variable X5 (The liberalization of the foreign exchange market) is highly correlated with X6 (Absence of Vibrant term market), X11 (Shifting from direct instruments to indirect instruments) and X13 (Disagreement between Bangladesh Bank \& commercial Bank over the use of ideal fund in real sector)at $1 \%$ level of significance. It has been identified that Variable X6 (Absence of Vibrant term market) is highly correlated with variables X11 (Shifting from direct instruments to indirect instruments) at 1\% level of significance.

It has also been found that Variable $\mathrm{X}_{7}$ (Positive operations of Central Bank Moral hazards) is highly correlated with variable X9(Behavior of board of directors \& managing directors) and X10(Mandatory reserve requirements) at $1 \%$ level of significance. The study has identified that Variable X8(Failure of legal reserve requirement to event out liquidity mismatches) has been found to be highly correlated with variable X9(Behavior of board of directors \& managing directors), X10(Mandatory reserve requirements) and X11 (Shifting from direct instruments to indirect instruments) at 1\% level of significance. The study has found that Variable X9(Behavior of board of directors \& managing directors) has been found to be highly correlated with variable X11(Shifting from direct instruments to indirect instruments) and X13 (Disagreement between Bangladesh Bank \& commercial Bank over the use of ideal fund in real sector) at 1\% level of significance. It is observed that Variable X10 (Mandatory reserve requirements) has been found to be highly correlated with variable X12 (Govt. debt management instruments) at $1 \%$ level of significance. The underlying relationship between variables is going to contribute to the formation of principal components.

\subsection{Principal Component Analysis}

The correlation matrix of all 13 variables has been further subjected to principal component analysis. The Eigen values, the percentage of total variance, and rotated sum of squared loadings have been shown in table 4.3. The factor matrix as obtained in the principal component analysis has also been further subjected to Varimax Rotation. An examination of Eigen values has led to the retention of 5 factors. These factors have accounted for $18.781 \%$, $18.454 \%, 16.338 \%, 13.254 \%$ and $8.994 \%$ of variation. This implies that the total variance accounted for by all five factors is $75.821 \%$ and the remaining variance is explained by other factors. The rotated factor matrix has been shown in Table 4.3. 
Table: 4.3 Principal Component Analyses.

\begin{tabular}{|c|c|c|c|c|c|c|c|c|c|}
\hline \multicolumn{10}{|c|}{ Total Variance Explained } \\
\hline \multirow{2}{*}{ Component } & \multicolumn{3}{|c|}{ Initial Eigen values } & \multicolumn{3}{|c|}{$\begin{array}{c}\text { Extraction Sums of Squared } \\
\text { Loadings }\end{array}$} & \multicolumn{3}{|c|}{$\begin{array}{l}\text { Rotation Sums of Squared } \\
\text { Loadings }\end{array}$} \\
\hline & Total & $\begin{array}{c}\% \text { of } \\
\text { Variance }\end{array}$ & Cumulative \% & Total & $\begin{array}{c}\% \text { of } \\
\text { Variance }\end{array}$ & Cumulative \% & Total & $\begin{array}{c}\% \text { of } \\
\text { Variance }\end{array}$ & Cumulative \% \\
\hline 1 & 3.673 & 28.250 & 28.250 & 3.673 & 28.250 & 28.250 & 2.442 & 18.781 & 18.781 \\
\hline 2 & 2.394 & 18.414 & 46.665 & 2.394 & 18.414 & 46.665 & 2.399 & 18.454 & 37.235 \\
\hline 3 & 1.649 & 12.683 & 59.348 & 1.649 & 12.683 & 59.348 & 2.124 & 16.338 & 53.573 \\
\hline 4 & 1.135 & 8.730 & 68.078 & 1.135 & 8.730 & 68.078 & 1.723 & 13.254 & 66.828 \\
\hline 5 & 1.007 & 7.743 & 75.821 & 1.007 & 7.743 & 75.821 & 1.169 & 8.994 & 75.821 \\
\hline 6 & .852 & 6.553 & 82.374 & & & & & & \\
\hline 7 & .580 & 4.460 & 86.834 & & & & & & \\
\hline 8 & .480 & 3.689 & 90.523 & & & & & & \\
\hline 9 & .367 & 2.824 & 93.347 & & & & & & \\
\hline 10 & .359 & 2.764 & 96.111 & & & & & & \\
\hline 11 & .246 & 1.891 & 98.002 & & & & & & \\
\hline 12 & .166 & 1.276 & 99.278 & & & & & & \\
\hline 13 & .094 & .722 & 100.000 & & & & & & \\
\hline
\end{tabular}

Source: Survey Instruments

Note: Data have been compiled by the researcher

This shows that variables under study have constituted five groups / factors which have been discussed in the following paragraphs.

4.3.1 Analysis of Factors

The five factors found from rotated factor matrix are orthogonal. Researcher has picked up variable with factor loading of 0.50 or above to have a particular factor.

Factor 1: Bank specific and Regulation Problems

\begin{tabular}{|l|l|c|}
\hline & \multicolumn{1}{|c|}{ Problems } & Factor loading \\
\hline X1 & Nonperforming loan creates liquidity problem & .788 \\
\hline X2 & Interest rate difference creates liquidity problem & .861 \\
\hline X13 & $\begin{array}{l}\text { Disagreement between Bangladesh Bank \& commercial Bank } \\
\text { over the use of ideal fund in real sector } \\
\text { Variance accounted for }\end{array}$ & .625 \\
\hline
\end{tabular}

Source: Survey Instruments

Note: Data have been compiled by the researcher

Factor-1 explains 18.781 percent of the total variations existing in the variable set. This includes variables$\mathrm{X} 1, \mathrm{X} 2$ and X13. This factor has very high significant factor loadings on these variables which have formed a major cluster. This factor belongs to Bank Specific and Regulatory Problems. So, this factor provides a basis for conceptualization of a dimension, which may be identified as Bank Specific and Regulatory Factor.

Factor 2: Regulatory and Policy Related Problems

\begin{tabular}{|l|l|c|}
\hline & \multicolumn{1}{|c|}{ Problems } & Factor loading \\
\hline X7 & Positive operations of Central Bank Moral hazards & .642 \\
\hline X8 & Failure of legal reserve requirement to event out liquidity mismatches & .809 \\
\hline X9 & Behavior of board of directors \& managing directors & .573 \\
\hline X10 & Mandatory reserve requirements & .745 \\
\hline & Variance accounted for & 18.454 \\
\hline
\end{tabular}

Source: Survey Instruments

Note: Data have been compiled by the researcher

Factor-2 explains 18.454 percent of the total variations existing in the variable set. This includes variables$\mathrm{X} 7, \mathrm{X} 8, \mathrm{X} 9$ and X10. This factor has also significant factors loading ranging from moderate to high on these variables which formed second important cluster. This factor is concerned with Positive operations of Central Bank Moral hazards, Failure of legal reserve requirement to event out liquidity mismatches, Behavior of board of directors \& managing directors and Mandatory reserve requirements.. So, this factor has provided a basis for conceptualization of a dimension, which may be identified as Regulatory and Policy Related Factor. 
Factor 3: Instrument and Market Related Problems

\begin{tabular}{|c|l|c|}
\hline & \multicolumn{1}{|c|}{ Problems } & Factor loading \\
\hline X3 & Asset liability mismatch has negative impact on liquidity & .624 \\
\hline X4 & $\begin{array}{l}\text { Commercial Bank in Bangladesh were quite unwilling to commit their resources } \\
\text { to long term investment }\end{array}$ & .761 \\
\hline X6 & Absence of Vibrant term market & .796 \\
\hline X11 & Shifting from direct instruments to indirect instruments & .555 \\
\hline & Variance accounted for & 16.338 \\
\hline
\end{tabular}

Source: Survey Instruments

Note: Data have been compiled by the researcher

Factor-3 explains 16.338 percent of the total variations existing in the variable set. This includes variables$\mathrm{X} 3, \mathrm{X} 4, \mathrm{X} 6$ and X11. This factor has high factor loadings on these variables which have formed a third important cluster. This factor is related to instrument and market of the instruments of the Banks. So. this factor has provided a basis for conceptualization of a dimension, which may be called Instrument and Market Related Factor.

Factor 4: Foreign Exchange Market Related Problem

\begin{tabular}{|l|l|c|}
\hline & Problems & Factor loading \\
\hline X5 & The liberalization of the foreign exchange market & .845 \\
\hline & Variance accounted for & 13.254 \\
\hline
\end{tabular}

Source: Survey Instruments

Note: Data have been compiled by the researcher

Factor-4 explains 13.254 percent of the total variations existing in the variable set This includes variable X5. This factor has high factor loadings on the variable, which has formed a fourth important cluster. This factor has provided a basis for conceptualization of a dimension, which may be called Foreign Exchange Market Related Factor.

Factor 5: Debt Instrument Problem

\begin{tabular}{|c|l|c|}
\hline & \multicolumn{1}{|c|}{ Problems } & Factor loading \\
\hline X12 & Govt. debt management instruments & .909 \\
\hline & Variance accounted for & 8.994 \\
\hline
\end{tabular}

Source: Survey Instruments

Note: Data have been compiled by the researcher

Factor-5 explains 8.994 percent of the total variations existing in the variable set. This includes variables$\mathrm{X} 12$. This factor has high factor loadings on these variables which have formed a fifth important cluster. This factor has provided a basis for conceptualization of dimension, which may be called Debt Instrument factor.

4.3.2 Ranking of Factors

Finally, the ranking obtained on the basis of factor - wise average scores are shown in the following Table- 4.3.2.

Table 4.3.2: Ranking of Factors

\begin{tabular}{|c|l|c|c|}
\hline Factor & Name & Weighted score & Rank \\
\hline 1 & Bank specific and Regulation Problems & 2.50 & V \\
\hline 2 & Regulatory and Policy Related Problems & 3.09 & I \\
\hline 3 & Instrument and Market Related Problems & 2.61 & IV \\
\hline 4 & Foreign Exchange Market Related Problem & 2.68 & III \\
\hline 5 & Debt Instrument Problem & 2.77 & II \\
\hline
\end{tabular}

Source: Survey Instruments

Note: Data have been compiled by the researcher

The factor rankings show the factor-2 regulatory and policy related problem as the first and most important factor. This factor includes variables such as Positive operations of Central Bank Moral hazards, Mandatory reserve requirements, Behavior of board of directors \& managing directors and Failure of legal reserve requirement to event out liquidity mismatches etc. This implies that the sample banks face challenges in liquidity management due to their policy and regulation authority. The second important factor is Debt Instrument Problem. This factor includes variables such as Govt. debt management instruments. This indicates that the sample banks face problems in liquidity management due to government debt instruments. The third important factor is the Foreign Exchange Market Related Problem. This implies that liquidity management of sample banks are facing problem for the liberalization of the foreign exchange market. The fourth important factor is Instrument and Market Related Problems which includes variables Asset liability mismatch, shifting from direct instruments to indirect instruments, Absence of Vibrant term market and Commercial Banks in Bangladesh were quite unwilling to commit their resources to long term investment. This ascertains that instruments and market forces create the challenges for sample banks' liquidity management. The fifth important factor is Bank specific and Regulation Problem that includes Non- performing loan creates liquidity problem, Disagreement between Bangladesh Bank 
\& commercial Bank over the use of ideal fund in real sector and Interest rate difference creates liquidity problem. This implies that bank specific factors and regulation are creating problems in liquidity management of sample banks.

\section{Conclusion}

The study has identified three important factors that show the problems associated with Liquidity Management of Commercial Banks. They are Regulatory and Policy Related Problems, Debt Instrument Problem and Foreign Exchange Market Related Problem. The first ranking factor 'Regulatory and Policy Related factor' is constituted by the variables which are Positive operations of Central Bank Moral hazards; Mandatory reserve requirements; Behavior of board of directors \& managing directors; and Failure of legal reserve requirement to event out liquidity mismatches. The second most important ranking factor 'Debt Instrument Problem factors' includes variable i.e. Govt. debt management instruments; and the third important ranking factor 'Foreign Exchange Market Related Problem Factors' supported by variables such as the liberalization of the foreign exchange market, Instrument and Market Related Problem, Asset liability mismatch, Shifting from direct instruments to indirect instruments, Absence of Vibrant term market and Commercial Bank in Bangladesh were quite unwilling to commit their resources to long term investment have been found to be the most important. Thus it has been found that the private commercial banks of Bangladesh should emphasize on the above mentioned factors in order to overcome the problems associated with the liquidity management.

\section{References}

Allen ,F. and Gale, D. (2000), Financial contagion, Journal of Political Economy, 108 (1), 1-33.

Allen, F. and Gale, D. (2004), Financial intermediaries and markets, Econometrica, 72, 1023-1061.

Freixas, X., Parigi, B. and Rochet, J.C. (2000), Systemic risk, inter-bank relations and liquidity provision by the Central Bank, Journal of Money Credit and Banking, 32(2), 611-638.

Froot, K. and Stein, J. (1998), A new approach to capital budgeting for financial institutions, Journal of Financial Economics, 47, 55-82.

Good friend, M. and Lacker, J. (1999), Limited commitment and Central Bank lending, Working Paper, Federal Reserve of Richmond.

Hoffman, P. and Santomero, A. (1998), Problem bank resolution: evaluating the options, Working Paper, University of Pennsylvania.

Holmström, B. and Tirole, J. (1998), Private and public supply of liquidity, Journal of Political Economy, 106(1), $1-40$.

Morgan, D. (2002), Rating banks: risk and uncertainty in an opaque industry, American Economic Review, 92 (4), 874-888.

Morris, S. and Shin H.S. (1998), Unique equilibrium in a model of self-fulfilling currency attacks, American Economic Review, 88(3), 587-597.

Morris, S. and Shin H.S. (2004a), Coordination risk and the price of debt, European Economic Review, 48(1), $133-153$

Morris, S. and Shin H.S. (2004b), Liquidity black holes, Review of Finance, 8(1), 1-18.

Rochet, J.C. (2004), Macroeconomic shocks and banking supervision, Journal of Financial Stability, 1(1), 93-110.

Rochet, J.C. and Tirole J. (1996a), Inter-bank lending and systemic risk, Journal of Money, Credit and Banking, $28,733-761$.

Rochet, J.C. and Tirole J. (1996b), Controlling risk in payment systems, Journal of money, Credit and Banking, $28,832-862$.

Rochet, J.C. and Vives X. (2004), Coordination failures and the lender of last resort: was Bagehot right after all?, Journal of the European Economic Association, 6(2), 1116-1147.

Selgin, G.A. (2004), Wholesale payments: questioning the market failure hypothesis, International Review of Law and Economics, 24, 333-350.

The Economist (2007), When to bail out: the case for more regulation of banks' liquidity, print edition of October $4^{\text {th }}$.

Tirole, J. (2006), The theory of corporate finance, Princeton University Press 